\title{
Pleura and lung
}

\author{
Stefan Diederich \\ From International Cancer Imaging Society (ICIS) 14th Annual Teaching Course \\ Heidelberg, Germany. 9-11 October 2014
}

Incidental pulmonary nodules in patients that are imaged for staging purposes or during follow-up may represent metastases, second primary tumours (lung cancer) or benign nodules.

The probability of pulmonary metastases or primary lung cancer differs depending on the number, size, size distribution and morphology of the nodules as well as the histologic type, stage, grade and other features of the known malignancy. A large proportion of pulmonary nodules in patients with known cancer are benign. Thus, an unconfounded diagnosis of pulmonary metastases has to be avoided in order not to falsely preclude potentially curative therapy of the primary tumour.

Synchronous or metachronous second primary lung cancers in a patient with a known lung cancer have to be differentiated from pulmonary satellite nodules representing either advanced tumour stages or metastatic disease as they may be amenable to curative surgery.

Pulmonary consolidation or ground glass attenuation most often represents infection and other non-malignant pathology but may occasionally be due to malignant lesions.

Pleural effusions and focal or diffuse pleural thickening from benign causes need to be differentiated from lesions representing pleural carcinomatosis which represents metastastic disease.

During this course examples of different incidental pulmonary and pleural lesions will be demonstrated and recommendations and guidelines for the management of the findings will be presented.

\section{Published: 9 October 2014}

\section{References}

1. MacMahon H, Austin JH, Gamsu G, Herold CJ, Jett JR, Naidich DP, Patz EF Jr, Swensen SJ: Fleischner Society.Guidelines for management of small pulmonary nodules detected on CT scans: a statement from the Fleischner Society. Radiology 2005, 237:395-400.

2. Naidich DP, Bankier AA, MacMahon H, Schaefer-Prokop CM, Pistolesi M, Goo JM, Macchiarini P, Crapo JD, Herold CJ, Austin JH, Travis WD: Recommendations for the management of subsolid pulmonary nodules detected at CT: a statement from the Fleischner Society. Radiology 2013, 266:304-317.

3. Gould MK, Donington J, Lynch WR, Mazzone PJ, Midthun DE, Naidich DP, Wiener RS: Evaluation of individuals with pulmonary nodules: when is it lung cancer? Diagnosis and management of lung cancer. In Chest. Volume 143.. 3 edition. American College of Chest Physicians evidencebased clinical practice guidelines; 2013:93S-120S

4. Patel VK, Naik SK, Naidich DP, Travis WD, Weingarten JA, Lazzaro R, Gutterman DD, Wentowski C, Grosu HB, Raoof S: A practical algorithmic approach to the diagnosis and management of solitary pulmonary nodules: part 1: radiologic characteristics and imaging modalities. Chest 2013, 143:825-839.

5. Patel VK, Naik SK, Naidich DP, Travis WD, Weingarten JA, Lazzaro R, Gutterman DD, Wentowski C, Grosu HB, Raoof S: A practical algorithmic approach to the diagnosis and management of solitary pulmonary nodules: part 2: pretest probability and algorithm. Chest 2013, 143:840-846.

doi:10.1186/1470-7330-14-S1-041

Cite this article as: Diederich: Pleura and lung. Cancer Imaging 2014 14(Suppl 1):041.
Submit your next manuscript to BioMed Central and take full advantage of:

- Convenient online submission

- Thorough peer review

- No space constraints or color figure charges

- Immediate publication on acceptance

- Inclusion in PubMed, CAS, Scopus and Google Scholar

- Research which is freely available for redistribution
() Biomed Central
C Biomed Central

(c) 2014 Diederich; licensee BioMed Central Ltd. This is an Open Access article distributed under the terms of the Creative Commons Attribution License (http://creativecommons.org/licenses/by/4.0), which permits unrestricted use, distribution, and reproduction in any medium, provided the original work is properly cited. The Creative Commons Public Domain Dedication waiver (http://creativecommons.org/publicdomain/zero/1.0/) applies to the data made available in this article, unless otherwise stated. 